Egyptian J. Anim. Prod. (2011) 48(1):-11-18

\title{
PRODUCTIVE AND FINANCIAL ASSESSMENT OF INTENSIVE BARKI SHEEP PRODUCTION SYSTEM IN MATROUH GOVERNORATE, EGYPT
}

\author{
S. M. Alsheikh
}

Animal and Poultry Breeding Department, Desert Research Center, Matarya, P. O. Box 11753, Cairo, Egypt

\section{SUMMARY}

A dynamic flock model (DFM) of intensive Barki sheep production system in Matrouh Governorate is presented. The model studies the complexity of the reproduction management systems of three lambing in two years and the productive efficiency and financial return. The data for three production cycles were collected during 2006-2009 from a Barki flock of the Sustainable Development Center for Matrouh Resources, Desert Research Center, Ministry of Agriculture. The flock size was started by 367 yearling ewes, all joined for first time in September, 2006 with 30 fertile rams in matting groups. According to the first meeting result, the ewes divided into two batches. First batch including the pregnant ewes and other including non pregnant ewes. Productive traits studied were lambing \%, weaning \%, twining \%, mortality \% from birth to weaning $\%$, number of ewe joined, number of ewe lambing, number of lambs born, number of lambs weaned and replacement rate of yearling ewes. Financial indicators considered for each production cycle were gross output of flock product (lambs sold, wool, manure and culling animals) and gross margin. Input/output data of both batch's productivity and financial were analyzed at each phase corresponded to the characterization of the each batch flock. The results showed that The overall average of lambing \%, weaning \%, twining \% and mortality from birth to weaning $\%$ were $86 \%, 98 \%, 5 \%$ and $9 \%$, respectively. The differences of gross margin ranged between -32625 LE in first cycle to 21748 LE in third cycle. The gross output of lambs, wool, manure and culling animals in first production cycle was about $87 \%, 2 \%, 11 \%$ and $0 \%$, respectively of the total gross output. While, in second production cycle was $71 \%, 2 \%, 9 \%$ and $18 \%$, respectively and in third production cycle was $67 \%, 2 \%, 11 \%$ and $21 \%$, respectively. It could be concluded that productive studied traits were better than investigated by other research paper, except that weaning \%, which led to less sold lambs, which effected on financial return. Finally, could be investigated that intensification Barki sheep production system in Matrouh governorate was not satisfied income, because the gross margin contributed $-23 \%, 8 \%$ and $12 \%$ for three studied production cycles, respectively.

Keywords: Sheep performance, dynamic model, North Western Coastal Zone and economic

\section{INTRODUCTION}

Barki sheep production system in Matrouh governorate is particularly extensive to the combination of production, reproduction and sales distribution differences (Aboul Naga et al., 1985). Up tell now, the intensive Barki sheep production systems were

Issued by The Egyptian Society of Animal Production 
not evaluated practically in Matrouh governorate of Egypt. In 2006, the Desert Research Center established intensive Barki sheep flock in Matrouh governorate. Therefore, the intensive management system could be a great assist increase lambing replacement rate. The intensification allows accelerated lambing patterns such as the three lambings in two years system (Cournut and Dedieu, 2004). The objective of this paper were productive and financial evaluation of Barki sheep intensive system and introducing a dynamic flock model (DFM), which study the complex replacement management system of three lambings in two years.

\section{MATERIALS AND METHODS}

\section{Flock management and Data collection:}

The Egyptian Barki sheep flock was established in year 2006 at Sustainable Development Center for Matrouh Resources, Desert Research Center, Ministry of Agriculture, Egypt. This center is located in Marsa Matrouh city, Matrouh governorate, longitudes $30^{\circ} 57^{\prime} \mathrm{E}$ and $30^{\circ} 41^{\prime} \mathrm{E}$ and latitudes $29^{\circ} 55^{\prime} \mathrm{N}$ and $29^{\circ} 25^{\prime}$ N. Animals were housed in semi open shaded pens. Feeds consisted mainly of concentrate feed mixture plus berseem hay (Trifolium alexantrinum) and rice or wheat straw all the round of the year. The concentrate feed mixture consisted of cottonseed cake, maize, wheat or rice bran, calcium carbonate, and sodium chloride. The average crude protein is $14 \%$. This mixture was fed once a day and water was available twice daily around noon after feeding and in late afternoon. Manure was collected each 4 month from the ewes' pens. The amount of the manure of the pens divided on number of ewes within each pens. Ewes were shearing once a year, the wool of each animal was weighted and collecting in one crop to sell. Weaning male lambs were directly soled, while weaning female lambs kept at one year old to use them as replacement with culling ewes. The data for three production cycles were collected during 2006-2009. The flock size was started by 367 yearling ewes, all joined for first time in September, 2006 with 30 fertile rams in matting groups. Rams were selected according to its own phenotypic performance related to breed characteristics. According to the first meeting result, the ewes divided into two batches (B1and B2). First batch including the pregnant ewes and other including non pregnant ewes. Three mating seasons are organized yearly; each season concerns one of the two batches. In a given year, a batch is mated in January and September, the other in May and vice versa in the next years. A mating period length is 34 days which elapsed for every mating in the whole flock. Suckling lasts for two months. At each production period, ewe lambs are mated for first time at 12 month old depending on live body weight (at least $30 \mathrm{~kg}$ ). At the end of a lambing season, the non-lambing ewes change batch. Ewes with health problems (e.g., mastitis, and nonmilking teats) were culled from flock.

\section{Productive traits:}

Productivity was recorded for each batch production cycle. Productive traits were number of ewe joined, number of ewe lambing, number of lambs born, number of lambs weaned and replacement rate of yearling ewes. In addition to calculated the following percentages traits:

Lambing $\%=$ (number of ewe lambed/ number of ewes joined) $* 100$.

Weaning $\%=$ (number of lambing weaned/ number of ewe lambed) $* 100$. 
Twining $\%=[(\text { No. of lambs born }- \text { No. of ewe lambing }) / \text { No. of ewe lambing }]^{*} 100$. Mortality $\%=[$ (No. of lambs born - No. of lambs weaned $) /$ No. of lambs weaned]*100.

\section{Financial indicators and analysis:}

Financial indicators were gross output of flock products (lambs sold, wool, manure and culling animals) and gross margin. Financial analysis was done for each batch production cycle in Egyptian pound (LE) (One USA $\$=5.57$ LE in October 2008) according to the following equations:

Variable cost $=$ feeding cost + labor cost

Feeding cost $=$ feeding price/head/day $*$ No. of ewes of both batch $* 120$ days .

Labor cost = labor salary per day $(15 \mathrm{LE}) * 4$ labor for both batch $* 120$ days.

Gross output $=$ sold return of lambs + wool + manure + culling animals .

Gross margin = gross output - variable cost.

Financial analysis did not include replacement of rams due to equal prices between culling rams with replacement rams. Also, the financial analysis was not included the fixed cost (i.e. animal purchase prices, buildings and administration). According to no record for veterinary services, the variable cost was not including veterinary cost. The input data and its official prices in LE were present in Table 1. These prices were obtained from the official Desert Research Center price list of animal and poultry products at 2006.

\section{Model analysis:}

Excel (2003) software was used to analyze the input/output data, which collected during 2006-2009. The four input variables (fertility, ewe lambing, lambs born and ewe replacement) of the model were assumed to be deterministic according to Wang and Dickerson (1991) and Blackburn and Cartwright (1987).

Table 1. Input data and its prices in LE (farm gate prices at 2006)

\begin{tabular}{llll}
\hline Item & Unit & Average production (head) & Prices/ unit/LE \\
\hline Weaned lambs & $\mathrm{Kg}$. & 20 & 25 \\
Culled ewes & $\mathrm{Kg}$. & 35 & 15 \\
Grease fleece weight & $\mathrm{Kg}$. & 2.5 & 2.5 \\
Manure / head / year & $\mathrm{m}^{3}$ & 3 & 40 \\
\hline
\end{tabular}

Characterization of dynamic flock model (DFM) of batch production cycle (BPC):

A conceptual of DFM of batch production cycle (BPC) is shown in diagram (1) with the time scale attached. The model covers a 3 year period (production cycles of three lambing in two years). The model was designed with 4 months as a time lag between the 2 batches. This means that the program was run over 3 years plus 4 months. A BPC is a part of DFM and defined as the aggregation of ewe production cycles around the same reproduction period. It corresponds to a combination of events linked to the management and biological processes that are characterized in relation to the production objective associated with it. It starts with the constitution of the mating batch and the introduction of the rams and ends when all the ewes get dry. This will be translated into the computer dynamic model by the allocation of a particular linkage of BPC to each batch and the definition of deadline dates for the end of drying off. The model constraints defined by the length of the unproductive 
period of ewes that failed at mating, involves entering these in the following BPC, which concern the other batch (via repeated mating and/or changes of batch when infertility is noted). The dynamic model depended on characterizing and meaning of reproduction and production cycle within each batch and between the two batches (i.e. replaced set of animals, introduction and disappearance of ewe lambs). The relation between productivity responses and ewe productive trajectory was the basic unit of the studied DFM performance and evolution. This DFM was dependent on four biological response variables.

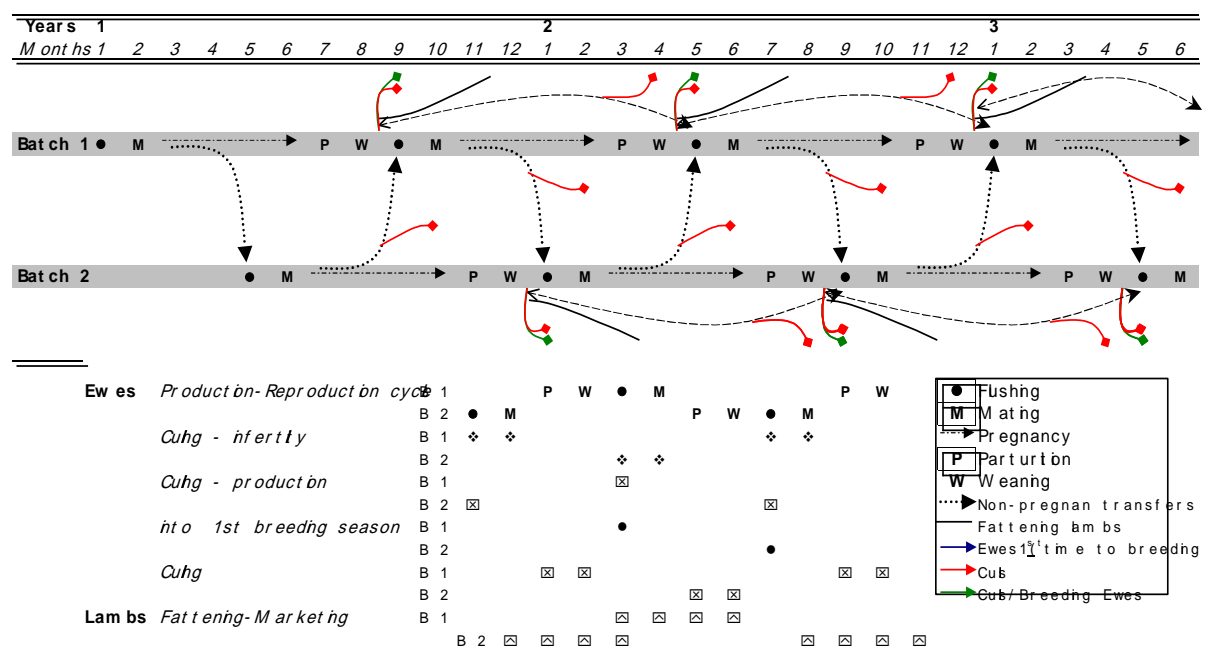

Diagram 1. A conceptual of Dynamic flock model of batch production cycle of three lambing in two years

The $1^{\text {st }}$ was the fertility, which is defined as the ability of ewe to be fertilized during a mating session. The $2^{\text {nd }}$ was ewe lambing, which is defined as the fecundation date and thus the lambing date. The $3^{\text {rd }}$ was the number of lambs born. The $4^{\text {th }}$ was replacement system, which is defined as the ewe productivity and not to be culled for involuntary reasons, health problems or death. All of fertility, lambing, number of lambs born and replacement system factors depend on defining all related affecting factors of ewes (i.e., mating season). The ewe trajectory was designed according to the succession of production events of the ewe and the path followed by this ewe through successive batch production cycles.

\section{RESULTS AND DISCUSSION}

\section{Productivity:}

The results of studies productive traits are shown in table 2 . The overall average of lambing \% was $86 \%$ (the range was $70-91 \%$ ). The overall average is higher than $70 \%$, which reviewed by Younis (1996). Moreover, comparing the overall average of weaning \% was $98 \%$ (the range was $89-94 \%$ ) with the $105 \%$ (the range was 99 $111 \%$ ) which reviewed by Younis (1996), it will observed that weaning \% in this study was less than the reviewed value. This result led to low number of weaned lambs sold, which effected on the gross output. Also, the overall average of twinning 
$\%$ was $5 \%$ (the range $2-7 \%$ ). This range was nearest to $2-10 \%$, which obtained by Ahmed (1990) in study on commercial flock While, the overall average of mortality $\%$ from birth to weaning was $9 \%$ (the range was $6-14 \%$ ), which higher than the range of 6-23\%, which obtained in the same study of Ahmed (1990).

Table 2. Productive traits

\begin{tabular}{|c|c|c|c|c|c|c|}
\hline Batches & $\begin{array}{l}\text { Mating } \\
\text { season }\end{array}$ & Crop & $\begin{array}{c}\text { Lambing } \\
(\%)\end{array}$ & $\begin{array}{c}\text { Weaning } \\
(\%)\end{array}$ & $\begin{array}{c}\text { Twinning } \\
(\%)\end{array}$ & $\begin{array}{c}\text { Mortality from } \\
\text { birth to } \\
\text { weaning }(\%)\end{array}$ \\
\hline \multicolumn{7}{|c|}{$1^{\text {st }}$ cycle of the two studied batches } \\
\hline B1 & Sept. 2006 & 1 & 84 & 93 & 4 & 11 \\
\hline B2 & Jan. 2007 & 2 & 70 & 113 & 2 & 9 \\
\hline B1 & May 2007 & 3 & 87 & 98 & 4 & 6 \\
\hline Average & & & 80 & 102 & 3 & 9 \\
\hline \multicolumn{7}{|c|}{$2^{\text {nd }}$ cycle of the two studied batches } \\
\hline B2 & Sept. 2007 & 4 & 91 & 100 & 7 & 7 \\
\hline B1 & Jan. 2008 & 5 & 91 & 99 & 6 & 7 \\
\hline B2 & May 2008 & 6 & 91 & 96 & 3 & 8 \\
\hline Average & & & 91 & 98 & 5 & 7 \\
\hline \multicolumn{7}{|c|}{$3^{\text {rd }}$ cycle of the two studied batches } \\
\hline B1 & Sept 2008 & 7 & 89 & 96 & $\overline{7}$ & 12 \\
\hline B2 & Jan. 2009 & 8 & 83 & 95 & 6 & 11 \\
\hline B1 & May. 2009 & 9 & 87 & 93 & 4 & 14 \\
\hline Average & & & 86 & 95 & 6 & 12 \\
\hline Overall a & erage & & 86 & 98 & 5 & 9 \\
\hline
\end{tabular}

Values rounded to the nearest integer.

\section{Dynamic Flock model:}

The DFM model output for productivity is shown in table (3). The fluctuations of the sizes of the two batches (B1 and B2) takes place as ewes are transferred back and forth, together with information on the lambing. Ewes have been removed from any of the two batches on their date of death. The total number of lambs sold over the 3 year of study as the time of first mating is changed. The model has been found to be remarkably stable system over the 3 studies years. Minimum levels of production are approximately $5 \%$ below maximum level. This is so despite the fact that detailed results for lamb sold in each batch showed little variation with changes of mating season. The number of lambs weaned also showed little variation between different mating seasons. The return value of sold lambs does not take seasonal fluctuations in lamb prices, which reflect normal supply and demand factors operative in North Western Coastal Zone environment.

\section{Financial return:}

The financial return of the three studied production cycles is presented in table (4). The model results showed that, these three cycles gave different gross output, which led to different gross margin. The differences of gross margin ranged between $-32625 \mathrm{LE}$ in first cycle to $21748 \mathrm{LE}$ in third cycle. The gross output of lambs, wool, manure and culling animals in first production cycle was about $87 \%, 2 \%, 11 \%$ and $0 \%$, respectively of the total gross output. While, in second production cycle was 
$71 \%, 2 \%, 9 \%$ and $18 \%$, respectively and in third production cycle was $67 \%, 2 \%$, $11 \%$ and $21 \%$ respectively. The results showed that the gross output of lambs sold was decreased from production cycle to another. While, gross output of wool was constant from production cycle to another. In contrast, the culling animals with increased from production cycle to another.

Table 3. Dynamic flock model output of productivity

\begin{tabular}{|c|c|c|c|c|c|c|c|c|}
\hline \multirow[b]{2}{*}{ Batchs } & \multirow[b]{2}{*}{$\begin{array}{l}\text { Mating } \\
\text { season }\end{array}$} & \multicolumn{6}{|c|}{ Number of. } & \multirow{2}{*}{$\begin{array}{l}\text { Replacement } \\
\text { Rate of } \\
\text { yearling } \\
\text { ewes }\end{array}$} \\
\hline & & Crop & $\begin{array}{l}\text { ewes } \\
\text { joined }\end{array}$ & $\begin{array}{l}\text { Ewes } \\
\text { lambing }\end{array}$ & $\begin{array}{l}\text { Ewes } \\
\text { barren }\end{array}$ & $\begin{array}{l}\text { Lambs } \\
\text { born }\end{array}$ & $\begin{array}{l}\text { lambs } \\
\text { weaned }\end{array}$ & \\
\hline \multicolumn{9}{|c|}{$1^{\text {st }}$ cycle of the two studied batches } \\
\hline B1 & $\begin{array}{l}\text { Sept. } \\
2006\end{array}$ & 1 & 367 & 310 & 57 & 322 & 290 & 0 out -0 in \\
\hline B2 & Jan. 2007 & 2 & 57 & 40 & 17 & 49 & 45 & 0 out -0 in \\
\hline B1 & May 2007 & 3 & 327 & 290 & 37 & 303 & 285 & 0 out -0 in \\
\hline Total & & & & & & & 620 & \\
\hline \multicolumn{9}{|c|}{$\underline{2}^{\text {nd }}$ cycle of the two studied batches } \\
\hline B2 & $\begin{array}{l}\text { Sept. } \\
2007\end{array}$ & 4 & 77 & 70 & 7 & 75 & 70 & 0 out- 0 in \\
\hline B1 & Jan. 2008 & 5 & 297 & 270 & 27 & 285 & 266 & 0 out- 0 in \\
\hline $\mathrm{B} 2$ & May 2008 & 6 & 160 & 146 & 14 & 151 & 140 & 20 out -30 in \\
\hline Total & & & & & & & 476 & \\
\hline \multicolumn{9}{|c|}{$3^{\text {rd }}$ cycle of the two studied batches } \\
\hline B1 & Sept 2008 & 7 & 328 & 293 & 35 & 313 & 280 & $\begin{array}{l}20 \text { out }-30 \\
\text { in }\end{array}$ \\
\hline B2 & Jan. 2009 & 8 & 240 & 199 & 41 & 210 & 190 & $\begin{array}{l}20 \text { out }-30 \\
\text { in }\end{array}$ \\
\hline B1 & May.2009 & 9 & 367 & 318 & 49 & 330 & 295 & $\begin{array}{l}20 \text { out }-30 \\
\text { in }\end{array}$ \\
\hline Total & & & & & & & 585 & \\
\hline Total of & crops & & & & & & 1681 & \\
\hline Averag & er season & & & & & & 186 & \\
\hline
\end{tabular}

Table 4. Financial analysis for three studies cycles.

\begin{tabular}{|c|c|c|c|c|c|c|c|c|c|}
\hline \multirow[b]{2}{*}{ Batch } & \multirow[b]{2}{*}{$\begin{array}{l}\text { Mating } \\
\text { season }\end{array}$} & \multirow[b]{2}{*}{$\begin{array}{l}\text { Batch } \\
\text { size }\end{array}$} & \multicolumn{2}{|c|}{ Variable Cost (LE) } & \multicolumn{4}{|c|}{ Gross output (LE) } & \multirow{2}{*}{$\begin{array}{l}\text { Gross } \\
\text { Margin } \\
\text { (LE) }\end{array}$} \\
\hline & & & Feeding & Labor & $\begin{array}{r}\text { Weaned } \\
\text { lambs }\end{array}$ & Wool & Manure & $\begin{array}{l}\text { Culling } \\
\text { ewes }\end{array}$ & \\
\hline \multicolumn{10}{|c|}{$1^{\text {st }}$ cycle of the two studied batches } \\
\hline B1 & Sept. & 367 & 44040 & 3600 & ----- & --- & --- & -- & \\
\hline B2 & Jan. & 57 & 44040 & 3600 & ----- & --- & 6000 & -- & \\
\hline B1 & May & 327 & 44040 & 3600 & 96000 & 2295 & 6000 & -- & \\
\hline \multicolumn{3}{|c|}{ Total / cycle (LE) } & \multicolumn{2}{|c|}{142920} & \multicolumn{4}{|c|}{110295} & -32625 \\
\hline \multicolumn{10}{|c|}{$\underline{2}^{\text {nd }}$ cycle of the two studied batches } \\
\hline B2 & Sept. & 77 & 68000 & 3600 & 51000 & --- & 7230 & -- & \\
\hline B1 & Jan. & 297 & 85521 & 3600 & 49000 & --- & 8625 & 15250 & \\
\hline B2 & May & 160 & 40810 & 3600 & 57400 & 3369 & 4200 & 25050 & \\
\hline \multicolumn{3}{|c|}{ Total / cycle (LE) } & \multicolumn{2}{|c|}{205131} & \multicolumn{4}{|c|}{221124} & 15993 \\
\hline \multicolumn{10}{|c|}{$\underline{3}^{\text {rd }}$ cycle of the two studied batches } \\
\hline B1 & Sept. & 328 & 55100 & 3600 & 58000 & --- & 9030 & 10550 & \\
\hline $\mathrm{B} 2$ & Jan. & 240 & 59565 & 3600 & 33600 & ---- & 7300 & 11350 & \\
\hline $\mathrm{B} 1$ & May & 367 & 55880 & 3600 & 43600 & 3559 & 6000 & 20050 & \\
\hline \multicolumn{3}{|c|}{ Total / cycle (LE) } & \multicolumn{2}{|c|}{181345} & \multicolumn{4}{|c|}{203093} & 21748 \\
\hline
\end{tabular}


It could be concluded that, this is a very simple DFM and clearly could be much improved if more detailed information were available on the inputs relating to reproductive and productive performances. Productive traits were better than investigated by other authors, except that weaning \%, which led to less sold lambs, which effected on financial return. Finally, could be investigated that intensification Barki sheep production system in Matrouh was not satisfied income, because the gross margin contributed $-23 \%, 8 \%$ and $12 \%$ for three studied production cycles, respectively.

\section{ACKNOWLEDGEMENT}

Sincere gratitude and appreciation are to Dr. M. F. A. Farid, Emeritus Professor of Animal Nutrition, Desert Research Center, for his propose the idea and design of the diagram (1) of this paper.

\section{REFERENCES}

Aboul Naga, A.M.,H. Mansour and E.A. Afifi, 1985. Genetic aspects of reproductive performance in two local fat-tail breeds of sheep. Egypt. J. Genet. Cyt., 14:11-20.

Ahmed A. M. 1990. Productive efficiency of sheep raised in newly reclaimed lands. M. Sc. Thesis, Faculty of Agric., Ain Shams Univ., Cairo, Egypt.

Blackburn, H.D. and T.C. Cartwright, 1987. Simulated production and biological efficiency of sheep flocks in shifting environment. J. Anim. Sci., 65:399-408.

Cournut S. and B. Dedieu, 2004. A Discrete event simulator of " three lambing in two years" intensive lamb production system. EAAP annul mating, 28 Augost-4 September, 2004, Blad, Slowvenia.

Wang C.T. and E. Dickerson, 1991. Simulated effects of reproductive performance on life-cycle efficiency of lamb and wool production at three lambing intervals. J. Anim. Sci., 69:4338-4347.

Younis A.A., 1996. Improving performance of Barki sheep through selection and crossing with other breeds. Preceding of a workshop on the development of animal production in the desert and newly reclaimed areas, Desert Research center, Cairo, Egypt, pp 1-6. 
التقييم الإنتاجى والمالى لمنظومة الإنتاج المكثف من الأغنام البرقى فى محافظة مطروح،

\section{سمير محمد الثيخ}

قسم تربية الحيوان والدواجن، مركز بحوث الصحراء ، المطريه, الثقاهر.

يتم عرض نموذج قطيع ديناميكى (DFM) لدنظومة تكثيف إنتاج الأغنام البرقي في محافظة مطروح. يهتم

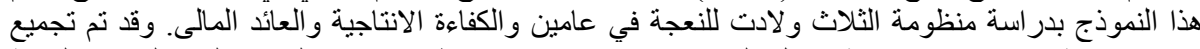

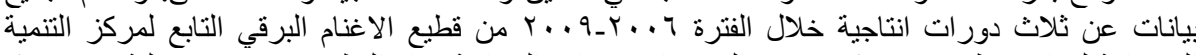

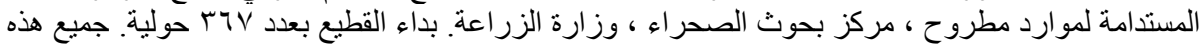

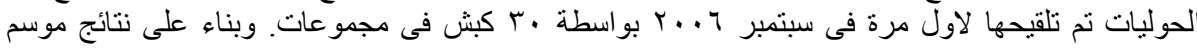

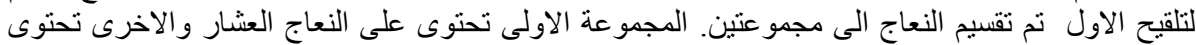

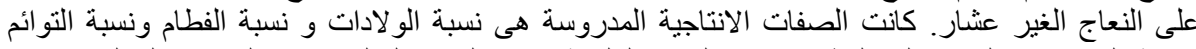

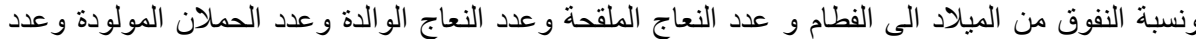

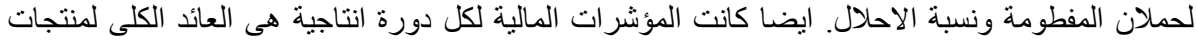

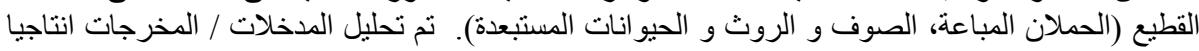

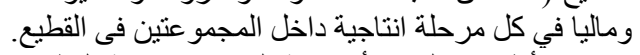

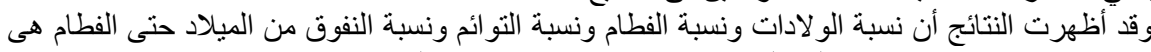

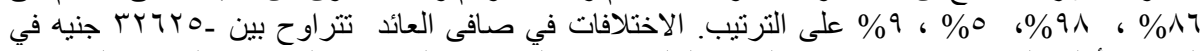

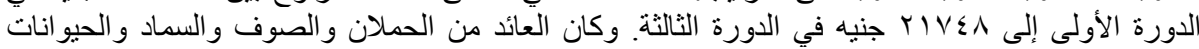

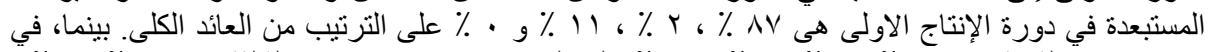

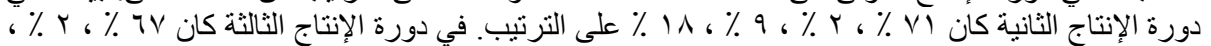

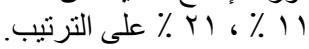

ويمكن أستخلص أن الصفات الانتاجية الددروسة كانت افضل من المتحصل عليها من البحاث الثاث اخرى،

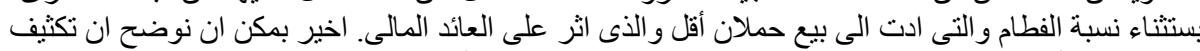

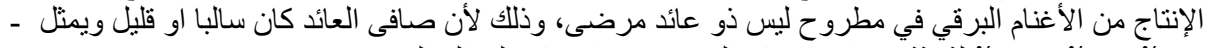

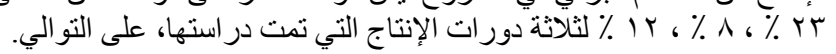

